УДК 35

https://doi.org/10.52058/2708-7530-2021-10(16)-152-161

Михайлов Віктор Миколайович кандидат наук з державного управління, доцент, заступник начальника інституту з наукової роботи, Інститут державного управління та наукових досліджень 3 цивільного захисту, вул. Вишгородська, 21, м. Київ, 02000, тел.: (063) 525-68-83, e-mail: mvn2006@ukr.net, https://orcid.org/ 0000- 0002-5629-1500

Андрієнко Микола Васильович доктор наук 3 державного управління, професор, полковник служби цивільного захисту, начальник науково-дослідного центру цивільного захисту, Інститут державного управління та наукових досліджень з цивільного захисту, вул. Вишгородська, 21, м. Київ, 02000, тел.: (067) 979-10-01, e-mail: andv@ukr.net, https://orcid.org/0000-0002-9222-4831

Гаман Петро Ілліч доктор наук 3 державного управління, професор, Заслужений працівник охорони здоров'я України, нагороджений орденом «За заслуги III ступеня», начальник відділу заходів захисту науково-дослідного центру цивільного захисту, Інститут державного управління та наукових досліджень 3 цивільного захисту, вул. Вишгородська, 21, Київ, 02000, тел.: (093) 700-86-63, e-mail: petro185@ukr.net, https://orcid.org/0000-0002-3239-8936

\title{
НАПРЯМИ ПІДВИЩЕННЯ ЕФЕКТИВНОСТІ ДЕРЖАВНОГО УПРАВЛІННЯ У СФЕРІ ЦИВІЛЬНОГО ЗАХИСТУ УКРАЇНИ В КОНТЕКСТІ ЄВРОПЕЙСЬКОГО ДОСВІДУ
}

Анотація. Ефективність, актуальність та дієвість державного управління $\epsilon$ запорукою стабільного стану суспільства загалом. Це стосується й України - в силу глобалізаційних та інформаційних перетворень, на перший план виходять інструменти боротьби із загрозами, що постають перед системою цивільного захисту (далі - ЦЗ).

Проблемою, що варта уваги, $є$ досить високий рівень інертності у структурно-інституційних та законодавчих галузях владно-урядового апарату в Україні. Окрім цього, реагування на загрози у вигляді тероризму, міграції населення, гібридних воєн та ін. є недостатньо оперативним та інтенсивним. Вищезазначене створює передумови до вивчення та вибіркового запозичення ідейно-теоретичних та політико-правових концепцій державного регулювання ЦЗ через призму досвіду країн-членів Свропейського Союзу.

Іншим питанням, що потребує викорінення, є спрямованість вітчизняної системи ЦЗ на нівелювання наявних наслідків НС природного та / або техногенного характеру, а не безпосередньо їх фактичну превенцію. Через це, 
досвід Європи зі створення попереджувальних механізмів НС та стихійних лих набуває особливої актуальності.

3 точки зору нормотворчого регулювання, в роботі варто зупинитися на положеннях Постанови КМУ № 11 від 09.01.2014 р. «Про затвердження Положення про єдину державну систему цивільного захисту» (далі - СДС ЦЗ). Власне, закон та його процедурна складова налічує достатньо колізійних епізодів (наприклад, фактична ліквідація системи ЦЗ у 2013 р. та ïi подальша «трансформація» після 2014 року тощо).

Окрім цього, для цілей статті важливо визначити систему державного управління у сфері Ц3 з точки зору пї базових принципових положень, порівнявши специфічні складові із аналогічними «вашингтонами», що закладені країнами Свропейського Союзу.

Ключові слова: система цивільного захисту, безпека населення, державноуправлінське реагування, попередження НС, ліквідація НС, боротьба зі стихійноструктурними «провокаторами».

Mikhailov Viktor Mykolayovych Candidate of Sciences in Public Administration, Associate Professor, Deputy Head of the Institute for Scientific Work, Institute of Public Administration and Research in Civil Defense, 21 Vyshhorodska St., Kyiv, 02000, tel.: (063) 525-68-83, e-mail: mvn2006@ukr.net, https://orcid.org/00000002-5629-1500

Andriyenko Mykola Vasyliovych Doctor of Science in Public Administration, Professor, Colonel of the Civil Defense Service, Head of the Civil Defense Research Center, Institute of Public Administration and Research in Civil Defense, 21 Vyshhorodska St., Kyiv, 02000, tel.: (067) 979-10-01, e-mail: andv@ukr.net, https://orcid.org/0000-0002-9222-4831

Gaman Petro Ilyich Doctor of Science in Public Administration, Professor, Honored Health Worker of Ukraine, awarded the Order of Merit of the Third Degree, Head of the Department of Protection Measures of the Civil Defense Research Center, Institute of Public Administration and Civil Defense Research, Vyshgorodskaya St., 21, Kyiv, 02000, tel.: (093) 700-86-63, e-mail: petro185@ukr.net, https://orcid.org/00000002-3239-8936

\section{DIRECTIONS OF IMPROVING THE EFFICIENCY OF PUBLIC ADMINISTRATION IN THE FIELD OF CIVIL DEFENSE OF UKRAINE IN THE CONTEXT OF THE EUROPEAN EXPERIENCE}

\footnotetext{
Abstract. The efficiency, relevance and effectiveness of public administration is the key to a stable state of society as a whole. This also applies to Ukraine - due to
}

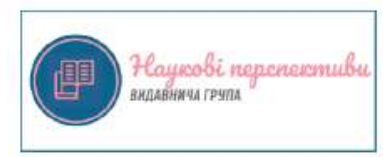


globalization and information transformations, the tools for combating the threats facing the civil protection system (hereinafter - CC) come to the fore.

A noteworthy problem is the rather high level of inertia in the structuralinstitutional and legislative branches of the government in Ukraine. In addition, responding to threats in the form of terrorism, population migration, hybrid wars, etc. is insufficiently operational and intensive. The above creates the preconditions for the study and selective borrowing of ideological-theoretical and political-legal concepts of state regulation of the Central Committee through the prism of the experience of member states of the European Union.

Another issue that needs to be eradicated is the focus of the domestic system of emergency response on leveling the existing consequences of natural and / or manmade emergencies, rather than directly their actual prevention. As a result, Europe's experience in creating emergency and disaster warning mechanisms is becoming particularly relevant.

From the point of view of normative regulation, the work should focus on the provisions of the Resolution of the Cabinet of Ministers № 11 of 09.01.2014 "On approval of the Regulations on a single state system of civil protection" (hereinafter EMU Central Committee). In fact, the law and its procedural component have a number of conflicting episodes (for example, the actual liquidation of the CP system in 2013 and its further "transformation" after 2014, etc.).

In addition, for the purposes of the article, it is important to define the system of public administration in the field of central government in terms of its basic principles, comparing specific components with similar "Washington", laid down by the European Union.

Keywords: civil protection system, public safety, public administration response, emergency prevention, emergency response, fight against natural and structural "provocateurs".

Постановка проблеми. Система ЦЗ прямо або опосередковано пов'язана із безпечним, стабільним середовищем для життя та існування громадян. Тому, необхідно говорити про необхідність «підлаштування» процедурних аспектів охорони соціального блага шляхом територіального та культурно-матеріального розвитку управлінської думки - за рамками, установленими СС.

Поміж тим, варто наголосити на необхідності впровадження механізмів охорони навколишнього природного середовища (далі - НПС) та підвищення наукового інтересу (як відомо, дана проблема в Україні не $є$ максимально вивченою) задля підтвердження фактично-предметного слідування курсу Євроінтеграції, закладеному в 2014 році.

Досвід країн-членів Свропейського співтовариства також можна спрямувати на вдосконалення та ефективізацію єдиної національної системи цивільного захисту (СДС ЦЗ). Аспекти іï керівництва, режиму функціонування та моніторингу мають вирішуватися за постулатами, закладеними у сфері ЦЗ на 
території Європи. Для цього актуально звернутися до історичного та перспективного процесу становлення захисту населення у СС.

Окремо варто звернути увагу на процес оповіщення та інформування про загрози або НС в Україні. Останній також має бути підлаштованим під концепти, закладені у Свропейському співтоваристві.

Аналіз останніх досліджень i публікацій. Питання ефективного державного управління у сфері цивільного захисту в Україні $є$ предметом дослідження багатьох вітчизняних вчених. У контексті зазначеного дослідження варто згадати науковий доробок В. Тищенко, О. Труша, Г. Ситника, В. Ліпкана, С. Мосова, Н. Нижника, А. Бойка та ін.

Мета статті - дослідити можливі шляхи підвищення ефективності державного управління у сфері ЦЗ України в контексті досвіду країн Європи.

Виклад основного матеріалу. В першу чергу, доцільним буде звернутися до термінології, що представлена у Постанові КМУ № 11 від 09.01 .2014 р. Наприклад, ЄДС ЦЗ визначено як управлінсько-засобові інструменти органів виконавчої влади (центральних та на місцях), Ради міністрів АРК та підприємницько-організаційних рад, діяльність яких спрямована на виконання державно-політичного курсу у галузі ЦЗ [1].

Необхідно зауважити, що дане положення частково походить від питання україно-європейського співробітництва у сфері Ц3, на якому в роботі буде зроблено віховий акцент. Початок кооперації датований ще 2008 роком — тоді у Брюсселі між Україною та ЄС було підписано Адміністративну домовленість «Навколишнє середовище» (сторони - MНС України 3 одного боку, Генеральний Директорат - 3 іншого).

Логічне та вмотивоване продовження певного вибіркового рецепіювання положень Свропейського Союзу в галузі НС відбулося у 2014 році - Угода про асоціацію між Україною та ЄС передбачала цивільно-захисне співробітництво (зокрема, Глава 6 «НПС») [2].

Надалі Державною службою України з надзвичайних ситуацій було вжито заходів щодо запозичення та впровадження на теренах України положень Директиви Європарламенту та Ради Європи 2012/18/СС від 04.07.2012 р. щодо контролю значних аварій, пов'язаних із небезпечними речовинами, та окремо Директиви 2007/60/СС від 23.10.2007 р. щодо оцінки та управління ризиками затоплення.

Потрібно нагадати, що на часі в Європі функціонує Механізм цивільного захисту СС (далі - МЦЗ СС). Останнім передбачається оперативне реагування на процеси виникнення $\mathrm{HC}$, допомога між країнами-членами Європейського співтовариства, взаємні зусилля щодо захисту майново-культурного комплексу країн Європи та презумпція його непошкодження / схоронності навіть у випадку стихійних лих, природних та / або техногенних катастроф. Можна відзначити, що для України приєднання до МЦЗ ЄС виглядає потребою часу, помноженою на євроінтеграційні вітчизняні тенденції. 
Ідеологічним продовженням вищезазначеної концепції управління ЦЗ у Європі слугує Єдина інформаційна система екстреної комунікації (CECIS). Вона дозволяє у найкоротші строки реагувати на «хвилювання» в області НС, технологічної, міграційної, ядерної безпеки тощо. Варто припустити, що більший відсоток «цифровізації» допоможе створити більш автентичні механізми владного регулювання в Україні. Зокрема, вирішення потребує відсутність будьякого нормування даного процесу основним профільним документом Кодексом цивільного захисту України № 5403-VI від 02.10.2012 р. (у редакції від 10.06.2021 p.) [3].

Водночас, частково-вибіркове регулювання ЦЗ на управлінському рівні за європейським концептом в Україні відбувалося протягом 2011 - 2019 рp. у рамках Програми СС для країн Східного партнерства (PPRD East). B рамках даної ініціативи ДСНС було поглиблено розуміння причин виникнення, вирішення та реагування на НC; покращено фактологічне та законодавчо-прогресивне підгрунтя задля кооперації у сфері Ц3 із іншими країнами та можливості вирішення цивільно-захисних колізій; слідування концептуальним положенням МЦЗ ЕС тощо.

У дійсності, для України важливо виокремити базові рекомендації Європейського співтовариства у сфері Ц3, поєднані із державно-управлінським та навчально-викладацьким інструментарієм націобезпекознавства. Сутність ЦЗ зводиться не лише до сухого законодавчого нагромадження термінології та суб’єктного складу його забезпечення : даний процес відображає владно-урядову спроможність реагувати на міжнародні та внутрішні дестабілізуючі виклики. Європарламент, Рада Європи та Єврокомісія демонструють спроможність створювати «цивільно-захисну оболонку», що забезпечує безпеку суспільства. Це, в свою чергу, кореспондує гуманно-правовим ідеологіям Європейського Союзу. Для України тут є що почерпнути : в першу чергу, згадується положення Основного закону - Конституції України, де у ст. 3 людину, іiі життя та здоров’я проголошено найвищою соціальною цінністю. Подібний пріоритет підлягає забезпеченню - зокрема, шляхом укорінення проєвропейських постулатів ЦЗ у вітчизняних правових ідеалах [4].

Зауважимо, що наразі на території Свропи та усього світу функціонує Всесвітня метеорологічна організація. Це установа, діяльність якої координує та спрямовує ООН. Основне завдання - перманентне спостереження за станом атмосфери Землі. Ще у 2012 році Україною було закладено підвалини кооперації iз даною установою. Проте більш активна позиція фахових установ (наприклад, Український гідрометеорологічний інститут ДСНС; НАН України) виступає не вимогою, а потребою часу.

Процедурно-конкретний базис урядування у сфері ЦЗ серед країн Європи, відтак, мабуть найефективніше відображений у Німеччині. Як зазначає О. Труш, система ЦЗ тут має історично-подвійне призначення. Компетентний профільний орган - Федеральне міністерство внутрішніх справ - займається зв'язком, 
реагування, сповіщенням, попередженням та контролем настання НС (та, відповідно, його превенції). Плани захисту, споруди задля охорони безпеки населення - профіль Служби захисту від катастроф. Дієва політика - створення добровільних громадських формувань на підприємствах (30+ працівників) у галузі аварійно-рятувального, протипожежного, медичного та попереджувального контролю [5].

Варто відмітити, що залучення населення до активного попередження наслідків (причин, передумов) виникнення НС - одне із пріоритетних державноуправлінських завдань для України. Таким чином відбувається формування громадської свідомості, правової культури та забезпечується стала, сформована СДС ЦЗ, про яку говориться у Постанові КМУ № 11 від 09.01.2014 р.

Досить вірним буде звернути увагу на державно-управлінський досвід Франції у сфері попередження та ліквідації НС. Тут даний процес є підсистемним елементом національно-оборонного комплексу. Міністерство внутрішніх справ комунікуе із спеціально створеним органом - Департаментом цивільного захисту. Таким чином, управління системою ЦЗ здійснюється із використанням муніципальних та загальнодержавних сил. Існують територіальні утворення, в межах яких «керують» окремі префекти. Окремо варто виділити Комітет зони оборони - орган дорадчого спрямування, представниками якого $є$ фахівці військових та цивільних органів реагування.

Себто, основний концепт ЦЗ у Франції полягає у поєднанні урядоводержавного курсу на загальному та місцевому рівнях відповідно. Ще одна риса - повноцінна готовність системних органів ЦЗ у мирний та воєнний час відповідно. Варто зазначити, що Україні було б доцільно почерпнути деякі управлінські ідеї - наприклад, розподіл повноважень між «центром» та «на місцях». Розгалужений апарат ЦЗ - ще один елемент дієвого, сучасного та превентивного державного управління даної сфери [5].

В той же час, досвід ЄС у сфері цивільного захисту можна розглядати через призму системи ЦЗ в Італії. Там функціонує два профільні органи : Департамент 3 питань цивільного захисту (ДПЦЗ) та Національна служба з питань цивільного захисту (НСЦЗ). Так, діяльність ДПЦЗ спрямовується Головою Ради Міністрів Італії, організаційно складаючись із восьми управлінь та сорока трьох служб. Цивільний захист контролюється на центральному, регіональному та периферійному рівнях. Система ЦЗ в Італії, водночас, включає до свого складу як громадський, так і приватний сектори (баланс державно-приватного інтересу). Власне, ДПЦЗ сприяє перевірці та контролю за системою ЦЗ загалом; здійснює моніторинг щодо превенції НC загалом та законодавче врегулювання контекстного нормативного базису; налаштовує інформаційні мережі на контроль за безпекою громадян та системою ЦЗ загалом.

Крім того, відзначимо ще одну особливість системи ЦЗ в Італії : комплексність. Цивільно-захисна функція держави виконується не лише ДПЦЗ та

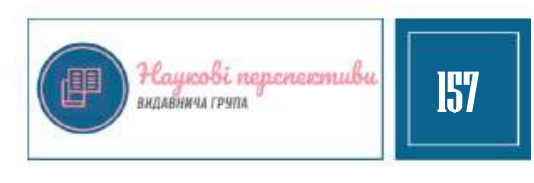


НСЦ3, але й Збройними силами, Фінансовою гвардією, Державним корпусом лісового господарства, Червоним хрестом та іншими різногалузевими органами.

Можна відмітити, що Україні буде корисним звернути увагу на розподіл повноважень між органами управління в Італії (в контексті Ц3), адже останній забезпечує безперебійний, ефективний та відкритий набір охороннопревентивних заходів із забезпечення блага людини та НПС як основних структурних одиниць соціальної структури суспільства [6].

Говорячи про досвід країн-членів СС у сфері ЦЗ, не зайвим буде зупинитися на Швеції. Так, в країні діє Управління Цивільної оборони (УЦО). Окремим органом зі спеціальним статусом визнається Національна рада 3 цивільної оборони (НРЦО). Обидва органи підзвітні та підконтрольні Міністрові оборони Швеції. Пріоритет країни - створення захисного бар'єру у вигляді споруд. Завдання уряду номер один - забезпечити кожного без виключення мешканця країни засобами індивідуального захисту на випадок НС, техногенної та / або природної катастрофи. Крім цього, в країні є сховища (глибина - 15-20 м, місткість - до 100 тис. осіб) [7].

Загалом, цивільна оборона Швеції може бути умовно розподілена на муніципальну та регіональну. Перша інваріація функціонує на дільницях, друга - переважно в округах та районах. Додатковий орган - Рятувальна служба, вирішує завдання у мирний час, ліквідує пожежі, аварії, повені та наслідки усіх видів дорожньо-транспортних пригод.

Необхідно зауважити, що для вітчизняної державно-управлінської думки буде важливим застосувати певні прикладні аспекти ЦЗ у Швеції. Наприклад, Україні варто запозичити скандинавський досвід щодо муніципально-регіонального управління, поєднавши його із дуальністю цивільнозахисної компетенції (УЦО та НРЦО) як елементом стабільності національної системи ЦЗ.

Повертаючись до центральноєвропейських країн, варто зупинитися на прикладі Австрії. Профільним органом у сфері цивільного захисту тут $\epsilon$ Федеральне міністерство внутрішніх справ (ФМВС). До його компетенції віднесено, зокрема, планово-запобіжні та організаційно-реагувальні заходи попередження НС та кризових ситуацій в країні. Інший профільний орган, Управління П/4 ФМВС, відповідає за цивільно-захисний стан населення та вирішення нагальних кризових ситуацій із використанням локалізаційноліквідаційного інструментарію ЦЗ.

Державно-управлінський устрій ЦЗ в Австрії має федеративно-районну специфіку (за схожим із Німеччиною концептом). Природні та / або техногенні загрози в країні долаються за допомогою колаборації цивільно-захисних підрозділів та звичайних громадян. При цьому, реалізація основ ЦЗ має два рівні - державний та федеративний.

Виконання умов цивільного захисту населення в Австрії має декілька структурних складових. Перша - попередження природних катастроф та 
технічних аварій. Друга — навчання самостійним основам захисту. Третя попередження та протидія загрозам на рівні щоденного моніторингу. Четверта способи та засоби попередження тероризму. 3 точки зору основ державноуправлінської теорії, даний підхід є вмотивованим - адже ми знаємо про «феномен політичного нейтралітету», що стосується власне Австрії, Швейцарії та Ірландії [8].

Ще один характерний момент із ЦЗ Австрії - діяльність «Альпійської служби», що виконує оперативно-рятувальні роботи (завдання) безпосередньо у гірській місцевості. Звісно, остання складова зумовлена тим, що близько 75\% населення Австрії складає гірська місцевість.

Де-факто, Україна може вибірково запозичити окремі ідеології Ц3, що є розповсюдженими в Австрії. Це, зокрема, стосується залучення громадян до процесу Ц3, регулярний моніторинг стану Ц3, навчання елементарним елементам самозахисту на випадок НС, техногенної та / або природної катастрофи тощо.

Надалі доцільним буде сконцентруватися на стані справ із ЦЗ у країнахсусідах України. Почати варто із Угорщини, де система ЦЗ повністю координується та спрямовується Головною дирекцією із надзвичайних ситуацій (ГДНС). Остання, в свою чергу, підзвітна Міністерству органів самоврядування та розвитку територій (МОСРТ). Таким чином, ГДНС покликана нівелювати та попереджувати настання $\mathrm{HC}$, та окремо - захищати суспільний інтерес та суспільне благо населення. Компетенція органу розповсюджується на пожежі, аварії, катастрофи тощо. Як і у випадку із Австрією, залученість у процес громадськості лише вітається та може заохочуватись власне ГДНС [9].

Власне ГДНС структурно можна розподілити на такі субелементи : профільні інспекції; органи управління виникненням та вирішенням проблем НС; господарський підрозділ $з$ питань НС.

Таким чином, Україні було б корисно використати деякі елементи системи Ц3 Угорщини, зокрема - щодо попередження НС та участі громади в даному процесі із координацією процесу уповноваженими (приклад - ГДНС та МОСРТ) територій.

Одночасно, у Польщі існує певний конгломерат відповідальних за забезпечення ЦЗ органів. До них, зокрема, відносяться : Головна комендатура пожежної охорони; Служба водного порятунку; Служба гірського порятунку; підрозділ Цивільної оборони. Функціонування здійснюється на загальнодержавному та муніципальному рівні. До інших органів зі спеціальною компетенцією у сфері ЦЗ Польщі відносимо Міністерство внутрішніх справ та адміністрації (MBCA) та два органи, що йому підконтрольні - Бюро з питань нівелювання стихійних лих та Департамент кризового управління оборонними справами. Відтак, досвід Польщі демонструє необхідність розгалуженої системи ЦЗ населення як передумови забезпечення ефективного регулювання даної сфери [10].

Висновки. Саме на це слід звернути увагу Україні : ЦЗ як політикосоціальний та владно-урядовий феномен має здійснюватися не лише за

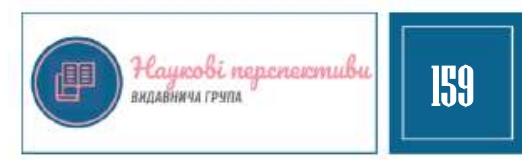


допомогою «статичного законодавства» накшталт Постанови КМУ № 11 від 09.01.2014 p. «Про затвердження Положення про єдину державну систему цивільного захисту» та Кодексу цивільного захисту України № 5403-VI від 02.10.2012 p. (у редакції від 10.06.2021 р.), але й практично-прикладних надбудов, що забезпечують гідне функціонування цивільно-захисної системи у сфері НС, технологічних та природних катастроф в Україні. Пріоритет — як і раніше, максимізація державно-управлінської ефективності шляхом налагодження проєвропейської конекції між усіма відповідальними урядовими органами.

\section{Лimepamypa:}

1. Постанова КМУ № 11 від 09.01.2014 р. «Про затвердження Положення про єдину державну систему цивільного захисту» // Відомості Верховної Ради // Режим доступу : https://zakon.rada.gov.ua/laws/show/11-2014-\%D0\%BF\#Text

2. Угода про асоціацію між Україною та ЄС (ред. від 30.11 .2015 р.) // Відомості Верховної Ради // Режим доступу : https://zakon.rada.gov.ua/laws/show/984_011\#Text

3. Кодекс цивільного захисту України № 5403-VI від 02.10.2012 р. (у редакції від 10.06.2021 р.) // Відомості Верховної Ради // Режим доступу : https://zakon.rada.gov.ua/ laws/show/5403-17\#Text

4. Конституція України 254к/96-ВР від 28.06.1996 р. (у ред. від 01.01.2020 р.) // Відомості Верховної Ради // Режим доступу : https://zakon.rada.gov.ua/laws/show/254\%D0\%BA/96$\% \mathrm{D} 0 \% \mathrm{~B} 2 \% \mathrm{D} 1 \% 80 \# \mathrm{Text}$

5. Труш О. Досвід побудови та функціонування систем цивільного захисту країн-членів Європейського Союзу Центральної Свропи, Харків, 2010 (наук, збірник).- с. 407-412.

6. Васійчук В. та ін. Основи цивільного захисту: навч. посібник / В.О. Васійчук, B.Є Гончарук, С.I. Качан, С.М. Мохняк. —Львів, 2010. — 417 с.

7. Федоренко В. Цивільний захист іноземних держав. Міжнародна організація цивільного захисту, Москва, 2003. - с. 275 - 283

8. Федулов Г. Зарубіжний досвід створення та забезпечення функціонування систем попередження та ліквідації надзвичайних ситуацій, 1998. - с. 63-75

9. Новаки М. Розвиток цивільного захисту Угорщини // Москва, 2018, Журнал : Надзвичайні ситуації : превенція, попередження // с. 89-95

10.Криножевськи Ф. Цивільна оборона Республіки Польща // Варшава (вид-во Difin), 2012.

\section{References:}

1. Postanova KMU № 11 vid 09.01.2014 r. «Pro zatverdzhennja Polozhennja pro єdinu derzhavnu sistemu civil'nogo zahistu» // Vidomosti Verhovnoï Radi // Rezhim dostupu : https://zakon.rada.gov.ua/laws/show/11-2014-\%D0\%BF\#Text

2. Ugoda pro asociaciju mizh Ukraïnoju ta $\mathrm{CS}$ (red. vid 30.11.2015 r.) // Vidomosti Verhovnoï Radi // Rezhim dostupu : https://zakon.rada.gov.ua/laws/show/984_011\#Text

3. Kodeks civil'nogo zahistu Ukraïni № 5403-VI vid 02.10.2012 r. (u redakciï vid 10.06.2021 r.) // Vidomosti Verhovnoï Radi // Rezhim dostupu : https://zakon.rada.gov.ua/laws/show/5403-17\#Text

4. Konstitucija Ukraïni 254k/96-VR vid 28.06.1996 r. (u red. vid 01.01.2020 r.) // Vidomosti Verhovnoï Radi // Rezhim dostupu : https://zakon.rada.gov.ua/laws/show/254\%D0\%BA/96$\% \mathrm{D} 0 \% \mathrm{~B} 2 \% \mathrm{D} 1 \% 80 \#$ Text

5. Trush O. Dosvid pobudovi ta funkcionuvannja sistem civil'nogo zahistu kraïn-chleniv Evropejs'kogo Sojuzu Central'noï Evropi, Harkiv, 2010 (nauk, zbirnik).- s. 407-412. 
6. Vasijchuk V. ta in. Osnovi civil'nogo zahistu: navch. posibnik / V.O. Vasijchuk, V.C Goncharuk, S.I. Kachan, S.M. Mohnjak. —L'viv, 2010. — 417 s.

7. Fedorenko V. Civil'nij zahist inozemnih derzhav. Mizhnarodna organizacija civil'nogo zahistu, Moskva, 2003. - s. 275 - 283

8. Fedulov G. Zarubizhnij dosvid stvorennja ta zabezpechennja funkcionuvannja sistem poperedzhennja ta likvidaciï nadzvichajnih situacij, 1998. — s. 63-75

9. Novaki M. Rozvitok civil'nogo zahistu Ugorshhini // Moskva, 2018, Zhurnal : Nadzvichajni situaciï : prevencija, poperedzhennja // s. 89-95

10. Krinozhevs'ki F. Civil'na oborona Respubliki Pol'shha // Varshava (vid-vo Difin), 2012. 